\title{
Carcinoma Lung Presenting as Intracranial Hypertension and Lower Cranial Nerve Palsies
}

\section{Chakor Rahul T* and Eklare Nishikant C}

Department of Neurology, TN Medical College, BYL Nair Hospital, Mumbai, India

“Corresponding author: Rahul Chakor, Associate Professor, Dept of Neurology, TN Medical College, BYL Nair Hospital, Mumbai, India, Tel: 9122 23027509; Fax: 91222302 0296; E-mail: drchakorrt@yahoo.co.in

Rec date: Apr 15, 2014, Acc date: May 29, 2014, Pub date: Jun 02, 2014

Copyright: $\odot 2014$ Chakor RT, et al. This is an open-access article distributed under the terms of the Creative Commons Attribution License, which permits unrestricted use, distribution, and reproduction in any medium, provided the original author and source are credited.

\begin{abstract}
Carcinomatous meningitis (CM) results from spread of malignant cells from solid tumors to leptomeninges and subarachnoid space. CM occurs in the late stage of cancer in the setting of widespread metastases. We report a patient presenting with intracranial hypertension, lower cranial nerve palsies and reactive CSF. His post contrast MRI brain and skull base was normal. Cerebrospinal fluid (CSF) was cellular but did not show malignant cells. Repeat CSF cytology the third time finally demonstrated carcinoma cells. A pulmonary mass was subsequently detected on high resolution computed tomogram (CT) of chest. CT guided biopsy was suggestive of adenocarcinoma.
\end{abstract}

Keywords: Carcinomatous meningitis; Intracranial hypertension; Papilloedema; Lower cranial nerve palsies; Lung carcinoma

\section{Introduction}

Carcinomatous meningitis (CM) results from spread of malignant cells from solid tumors to leptomeninges and subarachnoid space. CM occurs in the late stage of cancer. Rarely CM can be first manifestation of cancer [1]. We report a patient presenting with headache, papilloedema and multiple lower cranial neuropathies. CSF was cellular but did not show malignant cells. Repeat CSF cytology the third time finally demonstrated carcinoma cells. An adenocarcinoma of lung was subsequently detected.

\section{Case Report}

A 56 years old man presented with headache, vomiting, diminution of vision, dysphagia and hoarseness of voice since 20 days. There was no history of fever, seizures, altered sensorium. His general examination was normal. On neurological examination patient was drowsy but easily arousable with coherent speech. Cranial nerve examination showed diminished vision with perception of light in both eyes. Funduscopy revealed papilloedema. Bilateral palatal movements were decreased and gag reflex was absent. There was bilateral sternocleiodomastoid and trapezius wasting and weakness. Chest X-ray showed right upper lobe opacity which was thought to be due to aspiration. His post contrast MRI brain and MRI venography were normal. Lumbar puncture revealed elevated opening pressure (34 $\mathrm{cm}$ of $\mathrm{H}_{2} \mathrm{O}$ ). CSF analysis showed 20 cells (100\% lymphocytes) with normal proteins and sugar. To summarize patient had intracranial hypertension, papilloedema, bilateral IX, X, XI neuropathy and reactive CSF. A differential diagnosis of infective, inflammatory, neoplastic meningitis was considered. A repeat CSF study with CSF cytology showed atypical cells with eccentric enlarged hyperchromatic nuclei and anisonucleosis suggestive of carcinoma cells (Figure 1a and b). Subsequently a CT chest was done which revealed a mass in right upper lobe of lung. CT guided biopsy of the mass was consistent with adenocarcinoma.

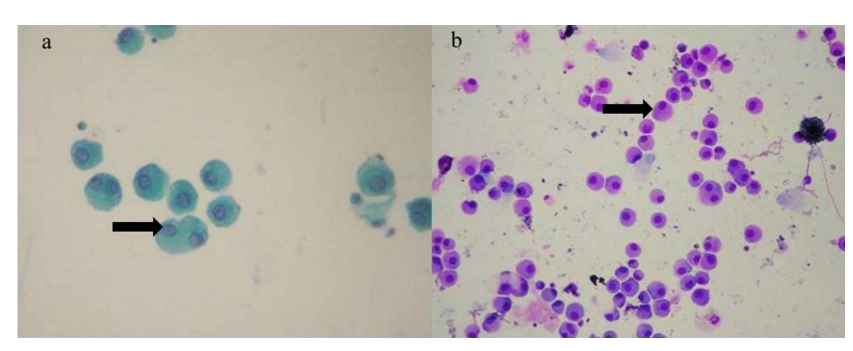

Figure 1a: PAP stain $(40 \mathrm{X})$ : Malignant cells with ovoid vesicular nuclei and occasional prominent nucleoli;Figure 1b: Giemsa stain $(10 \mathrm{X})$ : High cellularity with ovoid nuclei. Occasional cell shows signet ring appearance

\section{Discussion and Conclusion}

$\mathrm{CM}$ occurs in late stage of cancer most often in patients with systemic recurrence and failure of prior chemotherapy regimens $[1,2]$. Our patient did not have a known cancer. He presented with multiple lower cranial nerve palsies and papilloedema. His first CSF was reactive but absence of fever made us think of a non-infective process. Hence a repeat CSF study with cytology was done which revealed typical carcinoma cells (Figure 2a and b). CT chest detected a lung mass which turned out to be adenocarcinoma. Thus in patients with multiple cranial neuropathies and increased intracranial pressure carcinomatous meningitis should be differential diagnosis even in the absence of known cancer. CM may be presenting feature of carcinoma lung [3]. CSF cytology should be done repeatedly in patients with suspected CM. 
Citation: Chakor RT, Eklare NC (2014) Carcinoma Lung Presenting as Intracranial Hypertension and Lower Cranial Nerve Palsies. J Neurol Disord 2: 163. doi:10.4172/2329-6895.1000163

Page 2 of 2

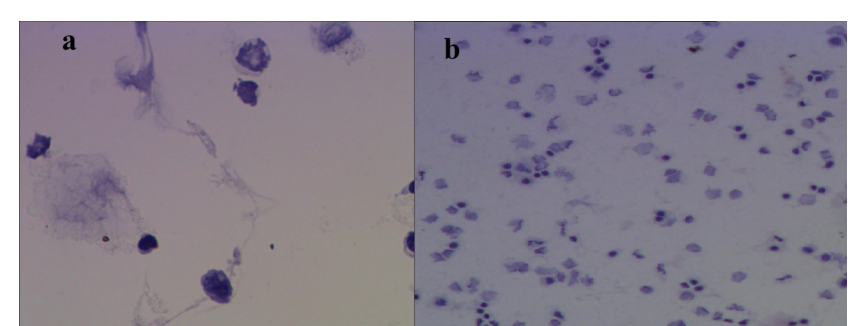

Figure 2a: PAP stain (40X) showing few scattered lymphocytes in normal CSF; Figure 2b: Giemsa stain (10X) showing few scattered lymphocytes in normal CSF

\section{References}

1. Chamberlain MC (2008) Neoplastic meningitis. Curr Neurol Neurosci Rep 8: 249-258.

2. Chamberlain MC (2008) Neoplastic meningitis. Oncologist 13: 967-977.

3. Paramez AR, Dixit R, Gupta N, Gupta R, Arya M (2010) Non-small cell lung carcinoma presenting as carcinomatous meningitis. Lung India 27: 158. 